\title{
Evaluation of pharmacy students' clinical interventions on a general medicine practice experience
}

\author{
Jocelyn D. JONES, Sylvia H. JACKSON, Aisha GOMEZ, Christie HOLLINGER, Gayle RIVERS.
} Received (first version): 25-Aug-2010 Accepted: 13-Dec-2010

\begin{abstract}
${ }^{*}$
As colleges of pharmacy prepare a new generation of practitioners, it is important that during practice experiences students learn the impact of clinical interventions. For over ten years, pharmacy students have been a vital part of the multidisciplinary team at the military treatment facility. The overall impact of the student interventions on patient care has not been evaluated. To evaluate the impact, the students began documenting their clinical interventions in Medkeeper RxInterventions ${ }^{\mathrm{TM}}$, an online database. The program is used to document faculty and fourth year pharmacy students' pharmaceutical interventions.

Objective: The objective of this study was to analyze the interventions completed by fourth year pharmacy students during a general medicine advanced pharmacy practice experience at a military treatment facility.

Methods: The students completing their general medicine advanced pharmacy practice experience at the military treatment facility are responsible for self reporting all interventions made during clinical rounds into the Medkeeper RxIntervention ${ }^{\mathrm{TM}}$ database. The researchers retrospectively collected and analyzed interventions made from June 2008 to June 2009.

Results: The total number of interventions recorded by 8 fourth year pharmacy students was 114 . Students averaged a number of 14.3 interventions during an eight week practice experience. Students spent an average of 5 minutes per intervention.
\end{abstract}

\footnotetext{
*Jocelyn D. JONES. Pharm.D., BCPS. Associate Professor of Pharmacy Practice. Florida Agricultural and Mechanical University College of Pharmacy and Pharmaceutical Sciences. Jacksonville, FL (United States).

Sylvia H. JACKSON., Pharm.D., MEd, CDE. Assistant Professor of Pharmacy Practice. Florida Agricultural and Mechanical University College of Pharmacy and Pharmaceutical Sciences. Jacksonville, FL (United States).

Aisha GOMEZ. Pharm.D. Candidate. Florida Agricultural and Mechanical University College of Pharmacy and Pharmaceutical Sciences. Jacksonville, FL (United States).

Christie HOLLINGER. Pharm.D. Candidate. Florida Agricultural and Mechanical University College of Pharmacy and Pharmaceutical Sciences. Jacksonville, FL (United States)

Gayle RIVERS. Pharm.D. Candidate. Florida Agricultural and Mechanical University College of Pharmacy and Pharmaceutical Sciences. Jacksonville, FL (United States).
}

Ninety- five percent of the interventions were accepted.

Conclusion: Fourth year pharmacy students' recommendations were accepted at a high rate by resident physicians. The high acceptance rate may have the ability to positively impact patient care.

Keywords: Students, Pharmacy. Education, Pharmacy, Graduate. United States.

\section{EVALUACIÓN DE LAS INTERVENCIONES CLÍNICAS DE LOS ESTUDIANTES DE FARMACIA EN UNAS PRÁCTICAS DE MEDICINA GENERAL}

\section{RESUMEN}

Mientras las facultades de farmacia preparan una nueva generación de facultativos, es importante que durante las prácticas tuteladas los alumnos aprendan el impacto de las intervenciones clínicas. Durante más de 10 años, los estudiantes de farmacia han sido un elemento vital del equipo multidisciplinario de la clínica militar. No se ha evaluado el impacto general de las intervenciones de los estudiantes en la atención a los pacientes. Para evaluar el impacto, los estudiantes comienzan a registrar sus intervenciones clínicas en Medkeeper RxInterventions ${ }^{\mathrm{TM}}$, una base de datos online. El programa se usa para documentar las intervenciones farmacéuticas de los profesores y los estudiantes de cuarto año.

Objetivo: El objetivo de este estudio fue evaluar las intervenciones completadas pro estudiantes de farmacia de cuarto año durante las prácticas tuteladas avanzadas en una clínica de medicina general de un establecimiento militar de tratamiento.

Métodos: Los estudiantes que realizan sus prácticas tuteladas avanzadas en el establecimiento militar de tratamiento son responsables de auto-comunicar todas las intervenciones realizadas durante las rondas clínicas en la base de datos Medkeeper RxIntervention ${ }^{\mathrm{TM}}$. Los investigadores recogieron y analizaron retrospectivamente las intervenciones realizadas entre junio 2008 y junio 2009.

Resultados: El número total de intervenciones registradas por los alumnos de farmacia de cuarto año fue de 114. Los estudiantes realizaron un promedio de 14,3 intervenciones durante sus ocho semanas de prácticas. Los estudiantes pasaron una media de 5 minutos por intervención. El 95\% de las intervenciones fueron aceptadas.

Conclusión: Las recomendaciones de los estudiantes de farmacia de cuarto año fueron 
altamente aceptadas por los médicos residentes. La alta tasa de aceptación puede tener la capacidad de impactar positivamente en los cuidados de los pacientes.

Palabras clave: Farmacia, Estudiantes. Educación, Farmacia, Graduada. Estados Unidos.

\section{INTRODUCTION}

Advanced pharmacy practice experience curriculums have expanded over the last decade to include enhanced training in developing individualized pharmaceutical care plans. The Accreditation Council for Pharmacy Education (ACPE) mandate that such experiences include direct interaction with diverse patient populations in various practice settings and involve collaboration with other healthcare professionals. ${ }^{1}$ Advanced pharmacy practice experiences provide fourth year pharmacy students with invaluable on-site experiences that prepare them for a more demanding and clinically involved role on the patient-oriented health care team. During clinical experiences, it has been proven that pharmacy students have an immense impact on medical interventions directly affecting patient care. Pharmacists and pharmacy students have demonstrated positive effects on patient care outcomes, including the prevention of adverse drug reactions and medication errors, improvement of patient satisfaction and quality of life, and improvement of economic outcomes. ${ }^{2-10}$

The opportunity to document interventions in an online database allows the interventions, recommendations, and actions to be recorded and reviewed to help evaluate its importance. In a study conducted by King et al, the significant impact pharmacy students have in identifying, recommending, and documenting clinical pharmacotherapeutic interventions was evaluated. ${ }^{10}$ The use of personal digital assistants (PDA) allowed students to document interventions while on medical rounds through the MedKeeper's intervention tracking program called RxRounds ${ }^{\mathrm{TM}}$. The interventions were divided into two categories: drug modification (prevention of adverse effects, drug substitutions, formulation/route changes, and interval modifications) and drug information (general consults, including pharmacokinetic consults, patient counseling, or any general information). ${ }^{10}$

At the end of the 12 week study, 50 interventions involved drug modifications and 54 interventions involved drug information. ${ }^{10}$ The majority of the interventions involved drug initiation and drug substitution. ${ }^{10}$ Only $2.2 \%$ of the interventions were rejected by the preceptors. ${ }^{10}$

As the practice of pharmacy evolves, doctor of pharmacy programs continue to expand their training to more hospital sites to expose pharmacy students to the management of various disease states. ${ }^{11}$ For over 10 years, pharmacy students have been an essential part of the medical team at the military treatment facility. The students attended medical rounds with family practice and internal medicine physicians, residents, and interns. The students had the opportunity to make significant interventions by reviewing the patient's medical chart, being a part of the patient discussion, and serving as a resource to the medical team. Over the years, various preceptors required pharmacy students to document their interventions using a paper system. These interventions are no longer available and were not evaluated.

In 2008, the preceptor implemented the documentation of clinical interventions as one of the fourth year pharmacy students' daily activities. The students documented the interventions using the Medkeeper RxInterventions ${ }^{\mathrm{TM}}$ program. This system helps to document cost savings, report the value of pharmacy activities, and justify staffing. ${ }^{12}$ Moreover, it allows organizations that subscribe to the program an opportunity to quickly and efficiently track clinical interventions, activities, adverse drug events, and medication errors. ${ }^{12}$ The purpose of this study was to analyze the interventions completed by fourth year pharmacy students during a general medicine advanced pharmacy practice experience at a military treatment facility.

\section{METHODS}

The university's College of Pharmacy and Pharmaceutical Sciences (COPPS) subscribes to the Medkeeper RxIntervention ${ }^{\mathrm{TM}}$ program. This application was developed to document clinical pharmacists' interventions. The COPPS utilizes the program to document faculty and fourth year pharmacy students' pharmaceutical interventions.

The researchers received approval from the institution's investigational review board to conduct the research. The participants were fourth year pharmacy students completing their General Medicine I and II advanced pharmacy practice experience at a 60 bed military treatment facility. The preceptor for the experience was a pharmacy practice faculty. During the 8 week experience, the participants were responsible for documenting all interventions. The completion of the interventions was not part of their final grade but it was a part of their daily activities. The participants began documenting the interventions in June 2008. The preceptor trained the students on the Medkeeper RxInterventions ${ }^{\mathrm{TM}}$ program. The preceptor defined the intervention categories, provided examples of interventions, and explained how to document the required information into the database. The students were responsible for voluntarily self reporting all interventions made during medical rounds. The students were encouraged to input interventions at least once a week. If an intervention was categorized as pending, the students were responsible for changing the status upon receiving the necessary information to one of the following: accepted or rejected.

The researchers retrospectively collected and analyzed interventions from June 2008 to June 2009. The researchers utilized the RxIntervention ${ }^{\mathrm{TM}}$ program to generate intervention reports based on 
requested parameters. In order to assess the data collected by the documentation system, the information was categorized into the appropriate identifiable categories that range from site of intervention (i.e. Naval Hospital), type of intervention, and response to intervention (i.e. accepted or rejected).

\section{RESULTS}

The total number of interventions recorded from June 2008 to June 2009 by 8 fourth year pharmacy students was 114. Each student averaged 14.3 interventions during an 8 week rotation period. This equates to 1.8 interventions per student per week. This number reflects interventions with the status of accepted, rejected and unknown. Students spent an average of 5 minutes per intervention. The average cost savings was USD563.00 per student. This information can be found in Table 1.

\begin{tabular}{|l|c|}
\hline \multicolumn{2}{|l|}{ Table 1. Student interventions documented between June } \\
2008 and June 2009. & Value \\
\hline Categorical Data & 114 \\
\hline $\begin{array}{l}\text { Total Number of Interventions documented } \\
(n=)\end{array}$ & 14.3 \\
\hline $\begin{array}{l}\text { Average Number of Interventions During 8 } \\
\text { week rotation per student (both accepted and } \\
\text { rejected) }\end{array}$ & $95.6 \%$ \\
\hline Percentage of Accepted Interventions & $5(1-10)$ \\
\hline $\begin{array}{l}\text { Average Time Spent per Intervention } \\
\text { (minutes) }\end{array}$ & $\begin{array}{c}563.00 \\
(200- \\
1250)\end{array}$ \\
\hline $\begin{array}{l}\text { Estimated Average Cost Savings } \\
\text { per student (USD) }\end{array}$ &
\end{tabular}

There were 65 categories listed for students to select as a description of the intervention performed. Of these 65 categories, 20 of these options were used more frequently. The most common interventions documented were drug information questions, drug therapy review, dosing consult, and antibiotic consult at $24 \%, 15 \%, 13 \%$, and $9 \%$ respectively. This information can be found in Table 2.

\begin{tabular}{|l|c|}
\hline \multicolumn{2}{|l|}{$\begin{array}{l}\text { Table 2. Percentages of the Most Frequently } \\
\text { Reported Interventions }\end{array}$} \\
\hline Drug Information & $30 \%$ \\
\hline Drug Therapy Review & $18 \%$ \\
\hline Dosing Consult & $17 \%$ \\
\hline Antibiotic Consult & $11 \%$ \\
\hline Pharmacokinetic Consult & $10 \%$ \\
\hline More Appropriate Dose & $9 \%$ \\
\hline More Appropriate Drug & $5 \%$ \\
\hline
\end{tabular}

Ninety five percent (109 of 114) of the interventions were accepted. There were 5 rejected interventions. Of the 5 rejected interventions, 3 were deemed unnecessary by the healthcare team due to the planned discharge of the patient. They were pharmacokinetic interventions, i.e. therapeutic drug levels or dosage changes for medications that the patients would no longer be receiving.

A total of 651 minutes (10.5 hours) was spent completing interventions. The average time spent per intervention was 5 minutes. Drug information consults required the most time to complete with the average being 30 minutes. Patient counseling, antibiotic consults, and drug therapy review required 20,15 , and 10 minutes to complete, respectively.

\section{DISCUSSION}

The acceptance rate in our study is consistent with other studies that have reported an acceptance rate of $64 \%$ to $97.9 \%$. $^{12-19}$ All recommendations were verbally presented to the physician. In two studies evaluating written versus oral recommendations made by pharmacy students, it was found that verbal recommendations had a higher acceptance rate. $^{18-19}$ Pound and Miller reported an $82.8 \%$ acceptance rate of verbal recommendations compared to $54.2 \%$ of written recommendations $(p<0.0001) .{ }^{18}$ In the Lundquist et al study, the acceptance of verbal recommendations versus written recommendations was $97.9 \%$ vs. $83.6 \%$, respectively. ${ }^{19}$ It was concluded that the higher rate of acceptance may be due to the student's face-toface time with the physician and the opportunity to engage in discussions regarding patient-specific recommendations. ${ }^{19}$ Additionally, during the 8 week experience the pharmacy students developed relationships with the resident physicians which may have led them to be more receptive to recommendations.

The 8 fourth year pharmacy students averaged 14.3 interventions in an 8 week period. This correlates to 1.8 interventions per student per week. Twentyseven students participated in the Dennehy et al study. ${ }^{14}$ The students were asked to document their interventions over a 5 day period during the first, third, and fifth week of a six week inpatient rotation. Students completed a total of 4.3 interventions per student per week. ${ }^{14}$ In a similar study by Chisholm et al, 15 students completed 2.9 interventions per student per week. ${ }^{20}$ It is uncertain as to why the number of interventions for this study group was smaller than those previously reported in the literature. But it can be postulated that the number of study participants may have been a contributing factor. It is also unclear whether the size of the facility may have been a factor because the size of the facility was not reported in the other trials referenced. In addition, Dennehy et al evaluated the associated drug cost of the interventions. The annualized drug costs indicated a savings of USD578.75 over the 15 day study period. ${ }^{14}$ Our study reported a cost savings per student of USD563.00 over the 8 week study period.

The most frequent type of intervention performed in our study was providing drug information (30\%). Two other studies illustrated similar results. The 3 year study conducted by Pham et al that included 63 fourth year pharmacy students reported that $46.8 \%$ of the interventions were providing drug information. ${ }^{12}$ A similar study by Slaughter et al which evaluated 6 post B.S. second year Pharm.D. students over 8 months found that $40.4 \%$ of all interventions were drug information related. ${ }^{8}$ A 3 year study by DiVall et al which included 83 students and 58 sites reported that the majority $(17.8 \%)$ of the interventions in the general medicine setting were dose adjustment. ${ }^{21}$ 
After evaluating the data, there are several possible limitations to this study that should be addressed. The students were responsible for voluntarily selfreporting their interventions at least weekly. There is the potential that the students may have forgotten or not reported all interventions made during the study period. There is also the possibility that students may not have reported rejected interventions. This could have reduced the total number of interventions made by the students. However, the students were instructed to document all interventions: accepted and rejected. Another possible limitation is that the students were responsible for classifying the interventions. The students were given instructions on how to classify their interventions as well as examples of each type of intervention. However, it is possible that the students may have incorrectly classified various interventions.

\section{CONCLUSIONS}

Training of healthcare professionals often involves participation on multidisciplinary teams. For 10 years at this military treatment facility, pharmacists and pharmacy students have been incorporated into the team. Until this study, there was no evidence to demonstrate the impact that pharmacy students have on the overall care of the general medicine patients in this practice setting. It is evident by the results of this study that the pharmacy students play a major role in making pharmacotherapy recommendations. The $95.6 \%$ acceptance rate reveals that the medical team was receptive of the pharmacotherapy recommendations. This study opens the door for the need of larger studies that evaluate the impact of pharmacy student clinical interventions at multiple advanced practice experience sites, exploration into the overall benefit of interventions based on the type or documentation method, and the potential cost-savings due to the avoidance of medication errors.

\section{CONFLICT OF INTEREST}

The authors have nothing to disclose.

\section{References}

1. Accreditation standards and guidelines for the professional program in pharmacy leading to the Doctor of Pharmacy degree. Adopted January 15, 2006. American council on Pharmaceutical Education, Chicago, 2006. Standard 14.

2. MacKinnon G. Analysis of pharmacy student interventions collected via an internet based system. Am J Pharm Educ. 2003;67(3):1-12.

3. Scarsi K, Fotis M, Noskin G. Pharmacist participation in medical rounds reduces medication errors. Am J Health-Syst Pharm. 2002;59:2089-2092.

4. Kucukarslan S, Peters M, Mlynarek M, Nafziger DA. Pharmacists on rounding teams reduce preventable adverse drug events in hospital general medicine units. Arch Intern Med. 2003;163:2014-2018.

5. Kaboli PH, Hoth AB, McClimon BJ, Schnipper JL. Clinical pharmacists and inpatient medical care. Arch Intern Med. 2006;166:955-964

6. Kane SL, Weber RJ, Dasta JF. The impact of critical care pharmacists on enhancing patient outcomes. Intensive Care Med. 2003;29:691-698.

7. Jennings HR, Poe K, Eberwein K, et al. Savings associated with the clinical activities of doctor of pharmacy students during advance pharmacy practice experiences. Am J Health-Syst Pharm. 2004;39:101D Presented at 2004 ASHP Midyear Clinical Meeting, Orlando, Florida.

8. Slaughter R, Erickson S, Thomson P. Clinical interventions provided by doctor of pharmacy students. Ann Pharmacother. 1994;28:665-670.

9. Sears E, Generali J. Adverse drug reaction and medication error reporting by pharmacy students. Ann Pharmacother. 2005;39:452-459.

10. King ED, Wilson MA, Van LY, Emanuel FS. Documentation of pharmacotherapeutic interventions of pharmacy students Pharmacy Practice (Internet). 2007;5(2):95-98.

11. Sauer BL, Heeren DL, Walker RB, King JH, Mussallam NA. Computerized documentation of activities of PharmD clerkship students. Am J Health Syst Pharm.1997;54:1727-1732.

12. Pham DQ. Evaluating the impact of clinical interventions by PharmD students on internal medicine clerkships: the results of a 3 year study. Ann Pharmacother. 2006 Sep; 40(9):1541-1545

13. Briceland LL, Kane MP, Hamilton RA. Evaluation of patient-care interventions by PharmD clerkship students. Am J Health Syst Pharm. 1992;49(5):1130-1132.

14. Dennehy C, Kroon L, Byrne M, Koda-Kimble MA. Increase in number and diversity of clinical interventions by PharmD. students over a clerkship rotation. Am J Phar Educ.1998;62:373-379.

15. Brockmiller H. Abel CP, Koh-KnoX CP, Birk CW. Cost impact of PharmD candidates' drug therapy recommendations. Am J Health Syst Pharm. 1999;56(9):882-884.

16. Taylor CT, Church CO, Byrd DC. Documentation of clinical interventions by pharmacy faculty, residents, and students. Ann Pharmacother. 2000;34(7):843-847.

17. Slaughter RL, Erickson SR, Thomson PA. Clinical interventions provided by doctor of pharmacy students. Ann Pharmacother. 1994;28(5):665-670.

18. Pound MW, Miller SM. Written versus oral recommendations made by pharmacy students during internal medicine rotations. Ann Pharmacother. 2007;41(5):772-776.

19. Lundquist L, Moye P. Resident physicians' acceptance of pharmacy students' pharmacotherapy recommendations during an ambulatory care advanced pharmacy practice experience. Am J Pharm Educ. 2009;73(8):1-4. 
Jones JD, Jackson SH, Gomez A, Hollinger C, Rivers G.. Evaluation of pharmacy students' clinical interventions on a general medicine practice experience. Pharmacy Practice (Internet) 2011 Jan-Mar;9(1):11-15.

20. Chisholm MA, Hawkins WE, Taylor AT. Providing pharmaceutical care: are pharmacy students beneficial to patients? Hosp Pharm. 1997; 32:371-373.

21. DiVall MV, Zikaras B, Copeland D et al. School-wide clinical intervention system to document pharmacy students' impact on patient care. Am J Pharm Educ. 2010;74(1);1-8. 